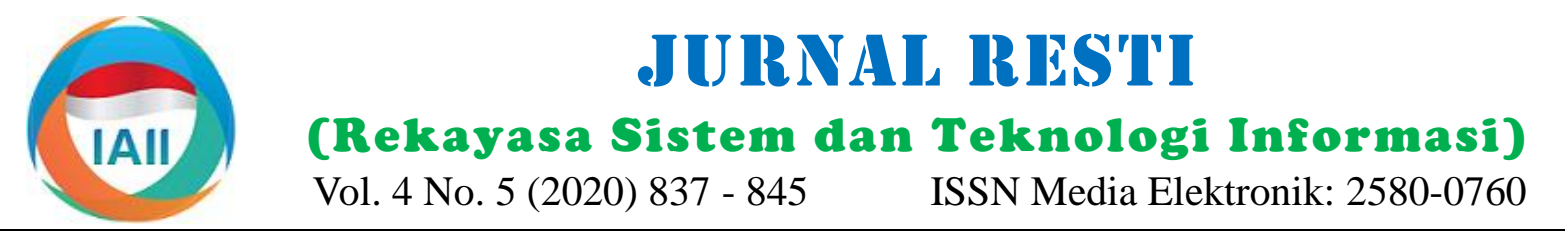

\title{
Desain Dempster Shafer dan Fuzzy Expert System dalam Mendeteksi Dini Penyakit Stroke
}

\author{
Laurentinus ${ }^{1}$ \\ ${ }^{1}$ Teknik Informatika, Fakultas Teknologi Informasi, ISB Atma Luhur \\ ${ }^{1}$ laurentinus@atmaluhur.ac.id
}

\begin{abstract}
The increasing population in Indonesia, which is 265 million people in 2018, causes an increase in the community's disease sufferers. Unfortunately, the number of hospitals in the area has not increased even though the population continues to grow, which impacts the community's lack of information and knowledge in dealing with some serious diseases such as stroke that attacks quickly. Stroke is the leading cause of disability and the number two cause of death in the world where 6.2 million people died in 2015 and is a complex medical problem that requires the diagnosis of a neurologist or internist. Still, not all doctors are in the district and provide services with fast. Temporary stroke symptoms are called transient ischemic attacks (TIA), which are warning signs before having a stroke, it requires how to recognize the signs of a stroke early and treat it as a medical emergency. Based on this problem, it is needed an expert system design that can diagnose stroke early and provide information about stroke to the community based on expert sources with an android mobile phone, making it accessible to the broader community, including in the district. The system design uses the Dempster Shafer Method to measure the uncertainty of 20 stroke symptoms. The disease slices outcome will produce a percentage of the likelihood of stroke, hypertension / high blood pressure, fever, and heart disease. As well as Fuzzy Logic as logical logic in processing 9 patient's medical history. The authors combined the two methods in providing a stroke diagnosis based on symptoms and patient history and then evaluated using several metrics, including accuracy, precision, sensitivity (recall), F-measure (F1 score), and specificity so that an expert system score was obtained of 0.786 which shows good expert system performance.
\end{abstract}

Keywords: expert system, stroke, fuzzy mamdani, dempster shafer, android

\begin{abstract}
Abstrak
Bertambahnya penduduk di Indonesia yaitu 265 juta jiwa pada tahun 2018 menyebabkan semakin meningkatnya jumlah penyakit di masyarakat. Namun Sayangnya, jumlah rumah sakit di daerah tidak meningkat walaupun jumlah penduduk terus bertambah, hal ini berdampak pada kurangnya informasi dan pengetahuan oleh masyarakat dalam menangani beberapa penyakit serius seperti stroke yang menyerang dengan cepat. Stroke merupakan penyebab utama kecacatan dan penyebab kematian nomor dua di dunia dimana 6.2 Juta manusia meninggal pada tahun 2015 dan merupakan masalah medis yang kompleks sehingga membutuhkan diagnosa seorang dokter syaraf atau dokter spesialis penyakit syaraf, akan tetapi tidak semua dokter ada di perdesaan dan memberikan pelayanan dengan cepat. Gejala stroke sementara disebut transient ischemic attacks (TIA) yaitu tanda peringatan sebelum mengalami stroke, dibutuhkan cara mengenali tanda-tanda stroke sejak dini dan memperlakukannya sebagai darurat medis. Berdasarkan permasalahan ini maka dibutuhkannya sebuah rancangan sistem pakar yang dapat mendiagnosa dini penyakit stroke serta memberikan informasi mengenai stroke kepada masyarakat berdasarkan sumber ahli yang berbasis mobile android sehingga dapat diakses oleh masyarakat luas termasuk di desa terpencil. Perancangan sistem menggunakan metode dempster shafer untuk mengukur ketidakpastian terhadap 20 gejala stroke dimana hasil dari irisan penyakit akan menghasilkan persentase kemungkinan terhadap penyakit stroke, hipertensi/darah tinggi, demam dan penyakit jantung. Serta penerapan Logika Fuzzy sebagai logika samar dalam mengolah 9 data riwayat medis pasien. Penulis menggabungkan kedua metode tersebut dalam memberikan diagnosis stroke berdasarkan gejala sakit serta riwayat pasien kemudian dievaluasi menggunakan beberapa metrik, termasuk akurasi, presisi, sensitivitas (recall), F-measure (F1 score), dan spesifisitas sehingga didapatkan nilai sistem pakar sebesar 0.786 yang menunjukkan kinerja sistem pakar yang baik.
\end{abstract}

Kata kunci: Sistem pakar, stroke, fuzzy mamdani, dempster shafer, android

Diterima Redaksi : 29-07-2020 | Selesai Revisi : 18-09-2020 | Diterbitkan Online : 30-10-2020 


\section{Pendahuluan}

Perkembangan teknologi informasi sekarang ini sudah menjangkau di segala bidang, salah satunya yaitu bidang kesehatan. Tidak dapat dipungkiri bahwa bidang kesehatan kini memerlukan teknologi informasi yang cepat dan akurat yang mampu meningkatkan efektifitas kinerja dalam bidang tersebut. Penyakit stroke merupakan sindroma klinis yang awal timbulnya mendadak, cepat, yang berupa defisit neurologis fokal atau global, yang berlangsung dibawah 24 jam atau jika telat ditangani akan langsung menimbulkan kematian. Masalah penyakit stroke di Indonesia memerlukan perhatian yang serius karena jumlah kasus yang terus meningkat dan mempunyai angka kematian yang tinggi terutama oleh masyarakat yang jauh dari perkotaan maka tingkat bahayanya akan meningkat. Salah satu penanganan yang diperlukan yaitu melakukan langkah langkah deteksi dini stroke dalam bentuk SKD (Sistem Kewaspadaan Dini) pada kejadian stroke, oleh karena itu infeksi pada hidung dapat menyebar ke tenggorokan dan sebaliknya.

Penelitian tentang sistem pakar fuzzy untuk diagnosis penyakit hipertensi yang dilakukan [1] menggunakan dua metode untuk diagnosis hipertensi. Pertama, sistem pakar Fuzzy (FE). Parameter masukan termasuk Systolic Blood Pressure (SBP) dan Body Mass Index (BMI). Kedua, multilayer neural network (MNN) dengan 5 masukan, 5 lapisan tersembunyi dan 1 keluaran digunakan untuk diagnosis hipertensi. Input tersebut antara lain SBP, merokok, usia, berat badan dan IMT. Penelitian tentang klasifikasi tingkat risiko Stroke menggunakan metode Tsukamoto GA-Fuzzy telah dilakukan [2] dengan menggunakan inferensi Fuzzy Logic, dari 15 data uji didapatkan akurasi $60 \%$. Sehingga untuk mengoptimalkan hasil tersebut, digunakan inferensi Fuzzy Tsukamoto dan Algoritma Penelitian ini melakukan riset di Rumah Sakit Bakti Genetika. Diketahui bahwa akurasi sistem dengan Timah (RSBT) oleh 1 dokter spesialis penyakit syaraf metode Fuzzy Tsukamoto-GA dalam optimalisasi batas seperti pada gambar 1 dimana proses pengumpulan data fungsi keanggotaan yaitu 86.66\%. Penelitian [3] melalui wawancara dan studi literatur logika fuzzy membahas tentang diagnosis penyakit jantung sehingga perancangan sistem pakar diagnosis dini berdasarkan logika fuzzy mediatif dengan tujuan penyakit stroke menggunakan logika fuzzy dapat merancang sistem pakar berdasarkan jenis logika fuzzy dicoding menghasilkan prototipe sistem. Evaluasi dan untuk mendiagnosis kemungkinan penyakit jantung bagi pengujian dilakukan oleh dokter spesialis penyakit pasien. Sistem yang diusulkan merupakan perpanjangan syaraf pada rumah sakit bakti timah kepada pasien dari kontroler logika fuzzy Mamdani dan berisi 44 secara acak.

aturan tipe input-output tunggal. Sistem bekerja dengan 11 variabel sebagai input dan satu variabel sebagai output. Penelitian [4] berjudul An intuitionistic fuzzy analytics for stroke disease mengusulkan sebuah pohon keputusan intuisi fuzzy untuk mendiagnosis berbagai jenis stroke. Pemetaan data observasi menerapkan pendekatan ini pada Intuitionistic Fuzzy Set. Dalam penelitian ini, hasil simulasi menunjukkan bahwa pendekatan berhasil menentukan 20 variabel yang berpengaruh langsung terhadap stroke. Lebih lanjut, pengujian menunjukkan bahwa pendekatan tersebut memiliki 90,59\% dalam mengklasifikasikan stroke. Hasilnya juga menunjukkan bahwa pendekatan ini menghasilkan kinerja diagnostik terbaik. Penelitian dalam pengembangan sistem pakar menggunakan fuzzy telah dilakukan dalam deteksi kecerdasan anak dan penyakit ginjal [5][6], perawatan bayi[7]. Secara khusus, penelitian mengenai penyakit stroke telah dilakukan dengan berbagai metode seperti dempster shafer dan generika[8][9]. Namun, penelitian diatas hanya menitik beratkan kepada satu algoritma sehingga memungkinkan terjadinya salah prediksi ataupun ketidak akuratan dikarenakan terdapat sangat banyak tor yang mempengaruhi seperti gejala hingga riwayat hidup pasien serta keluarganya dimana aspek ini membutuhkan teori yang berbeda dalam perhitungannya.

Dermasalahan ini maka diperlukan sistem yang yang dengan fungsi merupakan teori ketidakpastian dalam perhitungan terhadap gejala yang dialami pasien serta logika fuzzy yang merupakan logika samar untuk melakukan proses iwayat medis pasien terhadap hasil perhitungan gejala empster shafer. Analisis ini mengambil studi kasus pada rumah sakit bakti timah Pangkalpinang. Manfaat dari penelitian ini yaitu agar memberikan informasi erta deteksi penyakit stroke kepada masyarakat luas ang susah menjangkau Rumah Sakit untuk konsultasi. stroke tidak dapat dihentikan namun penanganan yang cepat dari pendeteksian dini sistem pakar akan memberikan dampak yang signifikan hingga terhindar dari kelumpuhan total atau kematian.

\section{Metode Penelitian}

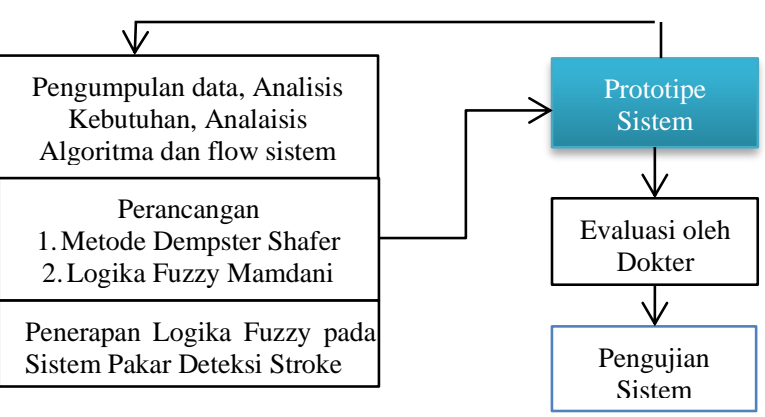

Gambar 1. Motode Penelitian Prototype pengambilan keputusan berbasis aturan berdasarkan 
a. Analisis Kebutuhan \& Pengumpulan Data

Pengumpulan data dilakukan terhadap gejala-gejala serta informasi penyakit stroke dari sumber seperti buku dan wawancara dengan dokter spesialis penyakit syaraf di tahun 2019.

\section{b. Desain Prototype}

Setelah mendapatkan serta mengetahui seluruh kebutuhan yang diperlukan dalam membangun aplikasi, maka dilakukan tahap desain prototype sesuai dengan tahapan pada gambar 2 dimana proses perhitungan dempster shafer dan fuzzy terhadap gejala dan riwayat pasien menghasilkan kesimpulan kemungkinan diagnosis penyakit.

c. Evaluasi Prototype

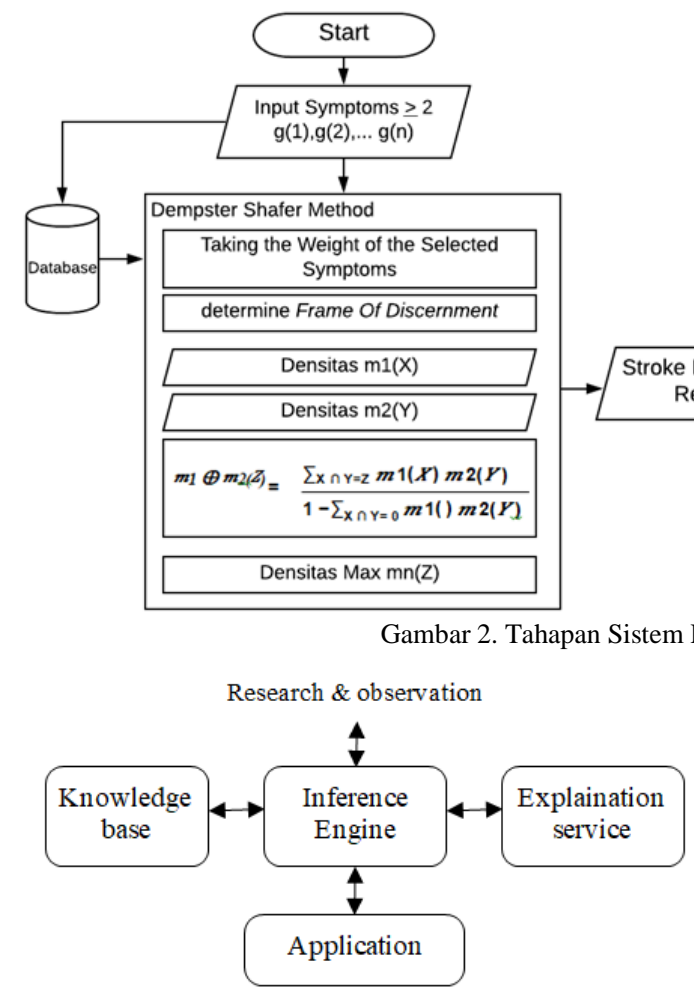

Gambar 3. Arsitektur Sistem Logika Fuzzy

Knowledge base pada riset ini yaitu untuk sumber pengetahuan mencakup kegiatan pencarian ahli, literatur berupa buku serta jurnal, dan data hasil wawancara dengan dokter spesialis penyakit syaraf rumah sakit bakti timah dalam kaitan penyakit stroke dan pendampingnya.

Mesin inferensi menjadi komponen sistem yang mengarahkan pengetahuan dari basis pengetahuan mengenai kepakaran stroke untuk mencapai kesimpulan seberapa besar kemungkinan pasien mengalami penyakit stroke. Dalam metode ini, kedua anteseden dan konsekuensinya adalah fuzzy set. Proses inferensi fuzzy dilakukan dengan: Fuzzifikasi, Evaluasi Rules, Hasil agregasi hasil evaluasi rules, dan Set keluaran fuzzy ke nilai tunggal (crisp).
Evaluasi ini dilakukan oleh user apakah prototyping yang sudah dibangun sudah sesuai dengan indentifikasi pakar dokter. Jika tidak sesuai maka prototype direvisi dengan mengulang langkah analisis kebutuhan, desain prototype, dan evaluasi prototype.

\section{d. Implementasi Sistem}

Dalam tahap ini prototyping yang sudah disepakati diterjemahkan ke dalam aplikasi sistem pakar.

\section{e. Pengujian Sistem}

Setelah sistem sudah menjadi suatu perangkat lunak yang siap pakai, harus di tes dahulu sebelum digunakan. Pengujian ini dilakukan dengan confusion matrix.

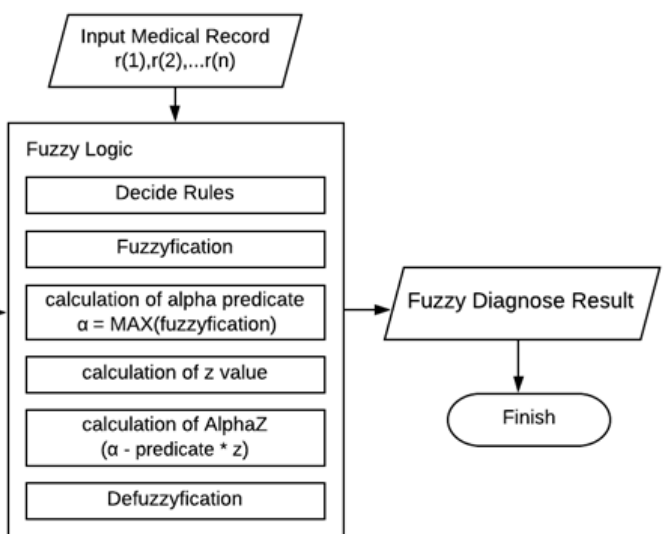

\subsection{Data Peneliian}

Pengumpulan data dilakukan oleh dokter spesialis dalam menghasilkan variabel-variabel berupa jenis-jenis penyakit stroke yang terdapat 4 variabel dan faktornya beserta 20 gejala-gejala dari penyakit stroke dapat dilihat pada tabel 1 dan tabel 2.

Tabel 1. Data Penyakit dan Faktornya

\begin{tabular}{cl}
\hline ID Penyakit & \multicolumn{1}{c}{ Nama Penyakit } \\
\hline 1 & Stroke \\
2 & Darah Tinggi / Hipertensi \\
3 & Demam \\
4 & Penyakit Jantung \\
\hline
\end{tabular}

Tabel 2. Data Gejala

\begin{tabular}{cl}
\hline ID Gejala & \multicolumn{1}{c}{ Nama Gejala } \\
\hline 1 & Sulit Menelan \\
2 & Pelupa / Kehilangan Konsentrasi \\
3 & Sakit Kepala Parah \\
4 & Gangguan Keseimbangan \\
5 & Kelemahan atau Kelumpuhan Anggota Tubuh \\
6 & Bicara Tidak Jelas / Pelo \\
7 & Rasa Kebas atau Baal \\
8 & Kesemutan Pada Sisi Tubuh \\
9 & Penglihatan Buram / Gangguan Penglihatan \\
10 & Kejang - Kejang \\
11 & Gerakan Sulit Dikoordinasi \\
12 & Pingsan \\
13 & Tidak Mampu Bicara / Menulis \\
\hline
\end{tabular}




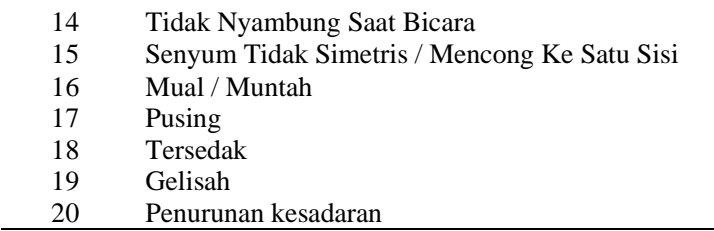

Data riwayat diperoleh dari riwayat pasien yang dapat memperburuk tingkat kemungkinan penyakit stroke. Terdapat 9 riwayat yang didiperoleh dapat dilihat pada tabel 3.

Tabel 3. Data Riwayat Medis

\begin{tabular}{cl}
\hline ID Riwayat & \multicolumn{1}{c}{ Nama Riwayat } \\
\hline 1 & Hipertensi \\
2 & Diabetes Melitus \\
3 & Kolesterol \\
4 & Berat Badan \\
5 & Faktor Genetik \\
6 & Usia \\
7 & Jantung \\
8 & Gangguan Pernapasan \\
9 & Kecanduan Zat Adiktif (Alcohol) \\
\hline
\end{tabular}

\section{Hasil dan Pembahasan}

Proses ini membahas tentang penerapan metode dempster shafer dan logika fuzzy kedalam sistem pakar deteksi stroke.

\subsection{Proses Algoritma Dempster Shafer}

Pada tahapan analisis ini, akan dilakukan penarikan kesimpulan relasi antara penyakit stroke dan gejalanya sesuai dengan data dari buku dan hasil wawancara yang telah dilakukan dengan dokter spesialis saraf. tabel relasi penyakit dan gejala pada sistem pakar diagnosa penyakit stroke dapat dilihat pada tabel 4.

Tabel 4. Relasi Penyakit Stroke dengan Gejala

\begin{tabular}{ccccc}
\hline \multirow{2}{*}{ Gejala } & \multicolumn{5}{c}{ Penyakit } \\
\cline { 2 - 5 } & $\mathbf{1}$ & $\mathbf{2}$ & $\mathbf{3}$ & $\mathbf{4}$ \\
\hline 1 & $\checkmark$ & & & $\checkmark$ \\
2 & $\checkmark$ & $\checkmark$ & $\checkmark$ & \\
3 & $\checkmark$ & $\checkmark$ & $\checkmark$ & $\checkmark$ \\
4 & $\checkmark$ & & $\checkmark$ & \\
5 & $\checkmark$ & & & \\
6 & $\checkmark$ & & & \\
7 & $\checkmark$ & & & $\checkmark$ \\
8 & $\checkmark$ & $\checkmark$ & & \\
9 & $\checkmark$ & $\checkmark$ & & \\
10 & $\checkmark$ & $\checkmark$ & $\checkmark$ & \\
11 & $\checkmark$ & & & \\
12 & $\checkmark$ & & & $\checkmark$ \\
13 & $\checkmark$ & & & \\
14 & $\checkmark$ & & & \\
15 & $\checkmark$ & & & \\
16 & $\checkmark$ & $\checkmark$ & $\checkmark$ & $\checkmark$ \\
17 & & $\checkmark$ & & $\checkmark$ \\
18 & & & & $\checkmark$ \\
19 & & & & $\checkmark$ \\
20 & & $\checkmark$ & & \\
\hline
\end{tabular}

Berdasarkan relasi data penyakit dan gejala pada tabel 4 maka dicari nilai belief yang menunjukkan kepastian yang dicantumkan pada persamaan (1).

$$
\operatorname{Bel}(X)=\sum_{Y \in X} m(Y)
$$

Plausibility Belief menjadi ukuran kekuatan evidence dalam mendukung suatu himpunan proposisi dan akan mengurangi tingkat kepastian dari evidence, Plausibility (Pls) dinotasikan pada persamaan (2).

$$
\operatorname{Pls}(X)=1-\operatorname{Bel}\left(X^{\prime}\right)=1-\sum_{Y \in X^{\prime}} m\left(X^{\prime}\right)
$$

\begin{tabular}{|c|c|c|c|}
\hline $\begin{array}{c}\text { Nama } \\
\text { Penyakit }\end{array}$ & Gejala & Belief & $\begin{array}{c}\text { Plausa } \\
\text { bility }\end{array}$ \\
\hline \multirow[t]{15}{*}{ Stroke } & Sulit Menelan & 0.3 & 0.7 \\
\hline & Pelupa / Kehilangan Konsentrasi & 0.3 & 0.7 \\
\hline & Sakit Kepala Parah & 0.5 & 0.5 \\
\hline & Gangguan Keseimbangan & 0.3 & 0.7 \\
\hline & Kelemahan atau & 0.5 & 0.5 \\
\hline & Bicara Tidak Jelas / Pelo & 0.5 & 0.5 \\
\hline & Rasa Kebas atau Baal & 0.3 & 0.7 \\
\hline & Kesemutan Pada Sisi Tubuh & 0.4 & 0.6 \\
\hline & Penglihatan Buram / Gangguan & 0.3 & 0.7 \\
\hline & Gerakan Sulit Dikoordinasi & 0.2 & 0.8 \\
\hline & Pingsan & 0.6 & 0.4 \\
\hline & Tidak Mampu Bicara / Menulis & 0.5 & 0.5 \\
\hline & Tidak Nyambung Saat Bicara & 0.2 & 0.8 \\
\hline & Senyum Tidak Simetris / Mencong & 0.5 & 0.5 \\
\hline & Mual / Muntah & 0.5 & 0.5 \\
\hline Darah & Sakit Kepala Parah & 0.5 & 0.5 \\
\hline \multirow{7}{*}{$\begin{array}{l}\text { Tinggi / } \\
\text { Hiperten } \\
\text { si }\end{array}$} & Pusing & 0.3 & 0.7 \\
\hline & Penglihatan Buram / Gangguan & 0.3 & 0.7 \\
\hline & Mual / Muntah & 0.4 & 0.6 \\
\hline & Kejang - Kejang & 0.4 & 0.6 \\
\hline & Pelupa / Kehilangan Konsentrasi & 0.3 & 0.7 \\
\hline & Kesemutan Pada Sisi Tubuh & 0.4 & 0.6 \\
\hline & Penurunan Kesadaran & 0.2 & 0.8 \\
\hline \multirow[t]{5}{*}{ Demam } & Sakit Kepala Parah & 0.5 & 0.5 \\
\hline & Kejang - Kejang & 0.4 & 0.6 \\
\hline & Mual / Muntah & 0.4 & 0.6 \\
\hline & Gangguan Keseimbangan & 0.3 & 0.7 \\
\hline & Pelupa / Kehilangan Konsentrasi & 0.3 & 0.7 \\
\hline Penyakit & Gelisah & 0.2 & 0.8 \\
\hline \multirow[t]{7}{*}{ Jantung } & Sulit Menelan & 0.3 & 0.7 \\
\hline & Rasa Kebas atau Baal & 0.3 & 0.7 \\
\hline & Pusing & 0.3 & 0.7 \\
\hline & Pingsan & 0.6 & 0.4 \\
\hline & Sakit Kepala Parah & 0.5 & 0.5 \\
\hline & Mual / Muntah & 0.4 & 0.6 \\
\hline & Tersedak & 0.3 & 0.7 \\
\hline
\end{tabular}

Tabel 5. Nilai Bobot Belief Gejala Penyakit 
Sehingga bila persamaan Dempster's Rule of Combination disubstitusikan ke persamaan evidential conflict (k) dapat dilihat pada persamaan (3).

$$
m 1 \oplus m 2(Z)=\frac{\sum X \cap Y=Z m 1(X) m 2(Y)}{1-\sum X \cap Y=\theta m 1(X) m 2(Y)}
$$

Dimana:

$\mathrm{m} 1 \oplus \mathrm{m} 2(\mathrm{Z}) \quad=$ mass function dari evidence $(\mathrm{Z})$

$\mathrm{m} 1(\mathrm{X}) \quad=$ mass function dari evidence $(\mathrm{X})$

$\mathrm{m} 2(\mathrm{Y}) \quad=$ mass function dari evidence $(\mathrm{Y})$

$\mathrm{k} \quad=$ jumlah evidential conflict

\subsection{Proses Algoritma Fuzzy Mamdani}

Data gejala akan diproses menggunakan metode 2. Mencari Rules dan Nilai Rancangan Kurva atau Nilai dempster shafer dan menghasilkan nilai akhir. Data Keanggotaan Untuk Setiap Variabel. Dari bobot gejala Selanjutnya yaitu Riwayat Pasien menjadi acuan Dokter dan bobot riwayat yang dipilih kemudian jumlahkan yang berpengaruh terhadap penyakit stroke. Hasil dari nilai bobot riwayat. Selanjutnya Cari rules dan nilai dempster shafer dan hasil akhir riwayat pasien akan keanggotaan dari setiap variable.

dihitung menggunakan logika fuzzy untuk mencari 3. Mencari Setiap Rules Dengan Fungsi Impilikasi tingkat kemungkinan pasien mengalami stroke.

Selanjutnya mencari nilai linguistik untuk setiap aturan Pada proses penelitian ini kriteria kelayakan untuk menggunakan fungsi implikasi dari nilai keanggotaan. pemberian nilai Linguistik direpresentasikan sebagai variabel input. Sedangkan variabel output pada proses ini berupa nilai linguistik.

Variabel Input yaitu nilai dempster shafer berdasarkan bobot yang memiliki nilai yang mendukung atau gejala, dan daftar riwayat atau rekam medis pasien yang dapat dilihat pada tabel 6. Variabel Ouput berupa nilai linguistik yang mana hasil nilai linguistik didapatkan dari variabel input gejala dan riwayat yang dapat dilihat pada tabel 7 .

Tabel 6. Data Fuzzy Set dan Nilainya terhadap Riwayat

\begin{tabular}{ccc}
\hline Nama Variabel & Fuzzy Set & Domain \\
\hline Hipertensi & tidak ada & {$[0]$} \\
Diabetes Melitus & ada & {$[1]$} \\
Kolesterol & adak ada & {$[0]$} \\
& tidak ada & {$[1]$} \\
Berat Badan & ada & {$[0]$} \\
& normal & {$[0,3]$} \\
& gemuk & {$[4,6]$} \\
Faktor Genetik & obesitas & {$[7,10]$} \\
& tidak ada & {$[0]$} \\
Usia & 1 sampai 2 & {$[1]$} \\
& Lebih dari 3 & {$[0]$} \\
Kecanduan Zat Adiktif & $<45$ & {$[0,3]$} \\
(Alcohol) & $45-55$ & {$[4,6]$} \\
Jantung & $>55$ & {$[7,10]$} \\
& tidak ada & {$[0]$} \\
Gangguan Pernapasan & ada & {$[1]$} \\
& ada & {$[0]$} \\
& tidak ada & {$[1]$} \\
& ada & {$[0]$}
\end{tabular}

4. Menentukan atau Mencari Nilai Defuzzyfikasi keseluruhan rules untuk nilai linguistiknya.

Program Jurnal

hipertensi, diabetes, kolesterol, berat, genetik, jenkel, usia, jantung, nafas, zat, bobot_stroke : float

total_riwayat, rules1, rules2, rules3, rules4, r1, r2, r3, r4, defuzzyfikasi : float

array_riwayat : array

Deskripsi Logika Fuzzy

input (hipertensi)

input (diabetes)

input (kolesterol)

input (berat)

input (genetik)

input (jenkel)

input (usia)

input (jantung)

input (nafas)

input (zat)

bobot_stroke $\leftarrow$ get_dempster_shafer_result()

array_push (array_riwayat, input)

while length.array_riwayat do total_riwayat += array_riwayat [ ]

/ /aturan fuzzy

bobot_stroke_sedikit=(100-bobot_stroke) $/ 100-20$

bobot_stroke_banyak= 1 - bobot_stroke_sedikit

bobot_riwayat_sedikit=(100-bobot_stroke $) / 100$ -

20

bobot_riwayat_banyak=1- bobot_riwayat_sedikit

if bobot_stroke_sedikit > bobot_riwayat_sedikit else then rules1 $\leftarrow$ bobot_stroke_sedikit

rules $1 \leftarrow$ bobot_riwayat_sedikit

$r 1 \leftarrow 100-(80 *$ rules 1$)$

if bobot_stroke_sedikit > bobot_riwayat_banyak then rules $2 \leftarrow$ bobot_stroke_sedikit

else

2 rules $2 \leftarrow$ bobot_riwayat_banyak

- $(80 *$ rūes 2$)$

if bobot_stroke_banyak > bobot_riwayat_sedikit then rules $\overline{3} \leftarrow$ bobot_stroke_banyak 


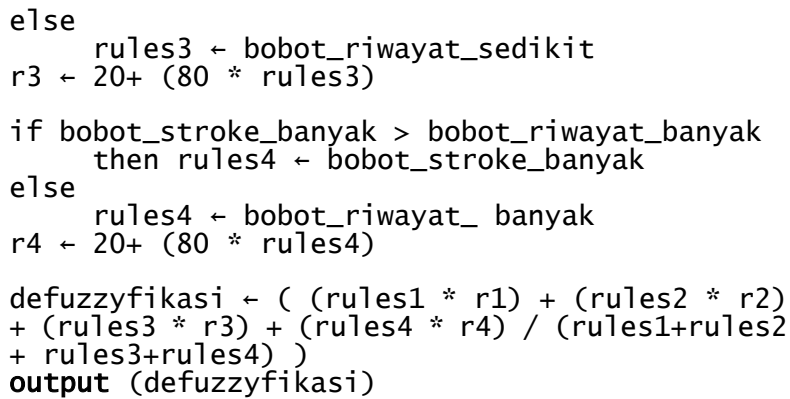

\subsubsection{Fuzzy Set}

Fungsi keanggotaaan variabel pada penelitian ini dibagi menjadi 2, variabel input dan variabel ouput. Variabel input terdiri dari gejala dan riwayat, sedangkan variabel output adalah nilai linguistiknya.

Secara umum, fuzzy set dalam sistem terdiri dari beberapa level, dapat dilihat pada gambar 4-6. Variabel yang berfungsi sebagai input dapat diwakili oleh kurva segitiga dan representasi linier sebagai berikut:

a. Kurang sistematis dapat diwakili oleh garis linier yang menurun.

b. Cukup sistematis dapat diwakili oleh representasi segitiga.

c. Sangat sistematis dapat diwakili oleh penyajian garis linier

Variable Gejala

Variabel Gejala ditunjukkan pada gambar 4, terdiri dari 4 himpunan fuzzy yaitu Tidak ada, Ringan, Sedang, dan berat.

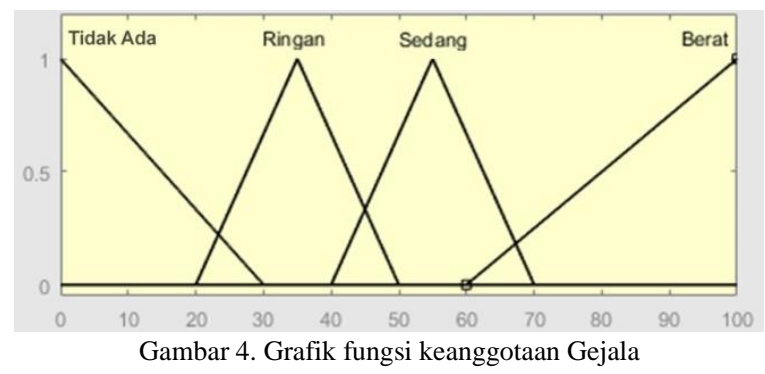

Gambar 4 merupakan grafik fungsi keanggotaan gejala berisi 4 himpunan yang dapat dilihat pada persamaan (4).

$$
\begin{aligned}
& \mu \text { Tidak Ada }\left\{\begin{array}{cc}
1 & x \leq 1 \\
(30-x):(30-0) & 0<x<30 \\
0 & x \geq 30
\end{array}\right. \\
& \mu \text { Ringan }\left\{\begin{array}{cc}
1 & x=35 \\
(x-20):(35-20) & 20<x<35 \\
(50-x):(50-35) & 35<x<50 \\
0 & 20 \leq x \leq 50
\end{array}\right. \\
& \mu \text { Sedang }\left\{\begin{array}{cc}
1 & x=55 \\
(x-40):(55-40) & 40<x<55 \\
(70-x):(70-55) & 55<x<70 \\
0 & 40 \leq x \leq 70
\end{array}\right. \\
& \mu \operatorname{Berat}\left\{\begin{array}{cc}
1 & x \geq 100 \\
(100-x):(100-60) & 60<x<100 \\
0 & x \leq 60
\end{array}\right.
\end{aligned}
$$

\section{Variable Riwayat}

Variabel Riwayat ditunjukkan pada gambar 5, terdiri dari 3 himpunan fuzzy yaitu Ringan, Sedang, dan berat.

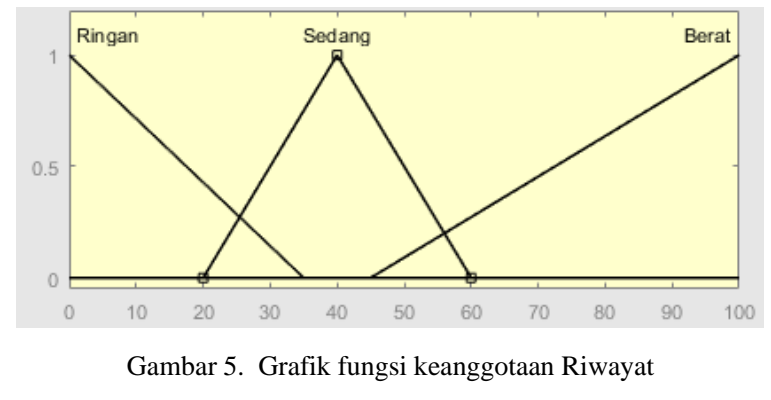

Gambar 5 merupakan grafik fungsi keanggotaan riwayat berisi 3 himpunan yang dapat dilihat pada persamaan (5).

$$
\begin{aligned}
& \mu \text { Ringan }\left\{\begin{array}{cc}
1 & x \leq 1 \\
(35-x):(35-0) & 0<x<35 \\
0 & x \geq 35
\end{array}\right. \\
& \mu \text { Sedang }\left\{\begin{array}{cc}
1 & x=40 \\
(x-20):(40-20) & 20<x<40 \\
(60-x):(60-40) & 40<x<60 \\
0 & 20 \leq x \leq 60
\end{array}\right. \\
& \mu \operatorname{Berat}\left\{\begin{array}{cc}
1 & x \geq 100 \\
(100-x):(100-45) & 45<x<100 \\
0 & x \leq 45
\end{array}\right.
\end{aligned}
$$

Variable Nilai Linguistik

Variabel Output Nilai Linguistik terdiri dari 2 himpunan fuzzy yaitu KECIL dan BESAR dapat dilihat pada gambar 6.

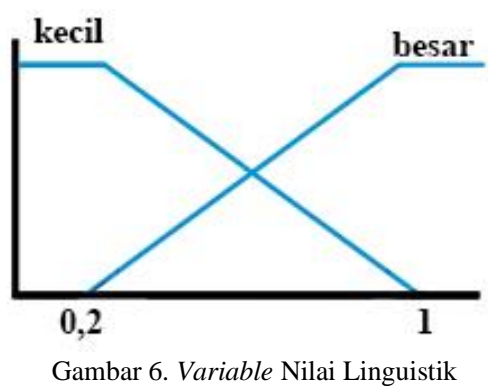

Inferensi berdasarkan rules

Nilai $\mu$ yang telah diperoleh dari tahap fuzzifikasi akan diterapkan untuk perhitungan rules. Karena terdapat banyak aturan maka ditampilkan beberapa rules sebagai berikut:

[R1] Jika nilai diagnosa kecil dan nilai riwayat kecil, maka variable linguistiknya "Kecil"

$\alpha$-predikat $1=\min (\mu$ diagnosaKECIL, $\mu$ riwayatKECIL $)$

$\mathrm{z} 1=(\mathbf{1 0 0}-$ bobot stroke $) /(\mathbf{1 0 0}-\mathbf{2 0})$

[R2] Jika nilai diagnosa besar dan nilai riwayat kecil, maka variable linguistiknya "Kecil" 
$\alpha$-predikat2 $=\quad$ min $\quad(\mu$ diagnosaBESAR, Tampilan Layar Gejala berisi daftar gejala yang $\mu$ riwayatKECIL) mungkin dialami pasien dapat dilihat pada gambar 8 .

z2=1- bobot stroke sedikit

[R3] Jika nilai diagnosa kecil dan nilai riwayat besar, maka variable linguistiknya "Kecil"

$$
\begin{aligned}
& \alpha \text {-predikat3 }=\quad \text { min } \quad \text { ( } \mu \text { diagnosaKECIL, } \\
& \mu \text { riwayatBESAR) } \\
& \mathrm{z} 3=(\mathbf{1 0 0} \text {-total riwayat) / (100-10); }
\end{aligned}
$$

[R4] Jika nilai diagnosa besar dan nilai riwayat besar, maka variable linguistiknya "Kecil"

$$
\begin{aligned}
& \alpha \text {-predikat } 4=\quad \text { min } \quad \text { ( } \mu \text { diagnosaBESAR, } \\
& \mu \text { riwayatBESAR) }
\end{aligned}
$$$$
\mathrm{z} 4=1 \text { - bobot stroke sedikit }
$$

defuzzyfikasi $=\alpha \operatorname{pred} 1 * \mathrm{z} 1+\alpha \operatorname{pred} 2 * \mathrm{z} 2+\operatorname{\alpha pred} 3 *$ z3 + apred4 $*$ z4/ (apred1+ apred2+ apred3 + apred4)

proses defuzzyfikasi merupakan proses terakhir dalam mengkonversi hasil apred dengan $\mathrm{z}$ dari inference engine yang diekspresikan dalam bentuk fuzzy set kesuatu bilangan real. hasil perhitungan defuzzyfikasi terhadap hasil gejala dan riwayat ditampilkan dalam skala 0 hingga 1 sesuai dengan variabel nilai linguistik pada fuzzy set dimana nilai 1 yaitu nilai tertinggi kemungkinan pasien terdeteksi penyakit stroke.

\subsection{User Interface}

Tampilan halaman home yang merupakan halaman menu utama dapat dilihat pada gambar 7, terdapat 4 menu yaitu konsultasi, tentang aplikasi, data gejala, dan info penyakit.

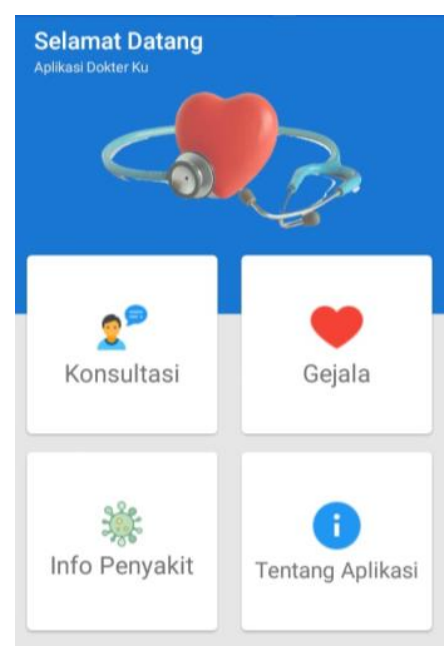

Gambar 7. Tampilan Layar Home

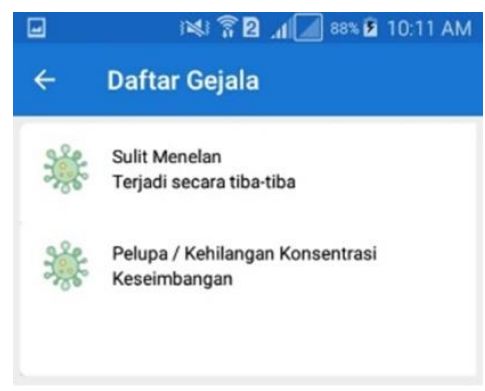

Gambar 8. Tampilan Layar Gejala

Tampilan Layar Penyakit berisi daftar penyakit dapat dilihat pada gambar 9.

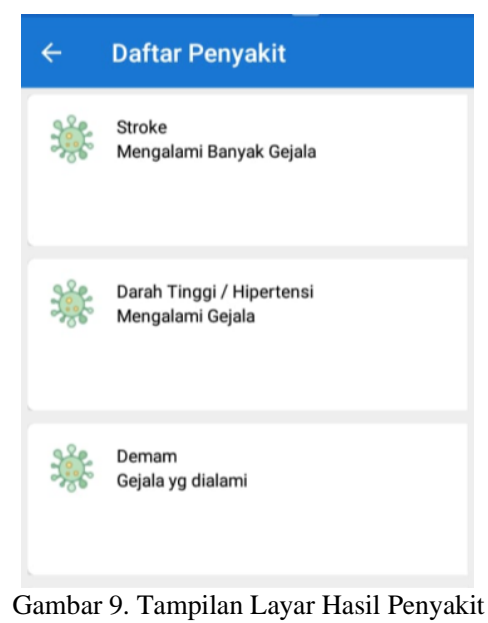

Tampilan konsultasi terdapat daftar gejala yang

\begin{tabular}{|c|c|}
\hline$\leftarrow \quad$ Konsultasi & DATA HASIL \\
\hline \multicolumn{2}{|l|}{$\begin{array}{l}\text { Sulit Menelan } \\
\text { Pelupa / Kehilangan Konsentrasi }\end{array}$} \\
\hline Sakit Kepala Parah & Stroke: $80.2 \%$ \\
\hline Gangguan Keseimbangan & Penyakit Jantung : $56.4 \%$ \\
\hline $\begin{array}{l}\text { Kelemahan atau Kelumpuhan Anggota } \\
\text { Tubuh }\end{array}$ & Darah Tinggi / Hipertensi : $54 \%$ \\
\hline Bicara Tidak Jelas / Pelo & Demam : $58 \%$ \\
\hline Rasa Kebas atau Baal & \\
\hline Kesemutan Pada Sisi Tubuh & \\
\hline Penglihatan Buram / Gangguan Penglihatan & Perhitungan Logika Fuzzy \\
\hline $\begin{array}{l}\text { Kejang - Kejang } \\
\text { Gerakan Sulit Dikoordinasi }\end{array}$ & Riwayat Hipertensi \\
\hline $\begin{array}{l}\text { Pingsan } \\
\text { Tidak Mampu Bicara / Menulis }\end{array}$ & Tidak ada \\
\hline $\begin{array}{l}\square \text { Tidak Nyambung Saat Bicara } \\
\text { Senyum Tidak Simetris / Mencong Ke Satu }\end{array}$ & Diabetes Melitus \\
\hline $\begin{array}{l}\text { Sisi } \\
\square \text { Mual / Muntah }\end{array}$ & Tidak ada \\
\hline$\square$ Pusing & \\
\hline Tersedak & Riwayat Kolesterol \\
\hline $\begin{array}{l}\text { Gelisah } \\
\text { Penurunan kesadaran }\end{array}$ & Tidak ada \\
\hline & Berat Badan \\
\hline
\end{tabular}
akan dipilih oleh masyarakat dapat dilihat pada gambar 10. Proses perhitungannya akan menampilkan hasil metode dempster shafer yang dilanjutkan proses input riwayat pasien yang akan diolah oleh logika fuzzy.

Gambar 10. Tampilan Layar Konsultasi 
Tampilan halaman hasil algoritma dempster shafer dan fuzzy ketika kita memilih gejala dan menekan tombol cek penyakit yang ada didalam halaman konsultasi dapat dilihat pada gambar 11 .

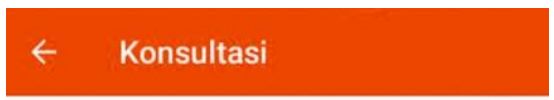

\section{Hasil Diagnosa Penyakit Anda}

Stroke : $66 \%$

Darah Tinggi / Hipertensi : $58 \%$ Penyakit Jantung : $72 \%$

Gambar 11 Tampilan Layar Hasil Konsultasi

\subsection{Pengujian Confusion Matrix}

Pengujian kepada user dilakukan dalam tanya jawab oleh dokter spesialis penyakit syaraf Rumah Sakit Bakti Timah kepada masyarakat yang ditanganinya. hasil penilaian ahli akan disesuaikan dengan sistem pakar sehingga diperoleh hasil.

Perancangan sistem logika fuzzy yang kami usulkan dievaluasi dengan menggunakan matriks konfusi yang berisi informasi kasus nyata dari pasien yang didiagnosis oleh dokter penyakit syaraf dan diagnosisnya diprediksi oleh sistem pakar fuzzy. Confusion Matrix pengklasifikasi dua kelas ditunjukkan pada tabel 8 dan data pengujian disajikan pada tabel 9.

Tabel 8. Confusion Matrix

\begin{tabular}{|c|c|c|c|}
\hline \multirow{2}{*}{$\begin{array}{l}\text { Confusion } \\
\text { Matrix }\end{array}$} & \multicolumn{2}{|c|}{ Prediksi } & керакаaаn yaitu dokter penyakit syarat ruman sakit baktı \\
\hline & Negatif & Positif & \\
\hline \multirow{7}{*}{ Negatif } & \multirow{7}{*}{$\begin{array}{l}\text { TN : banyaknya kasus } \\
\text { masyarakat yang } \\
\text { terdiagnosis tidak ada } \\
\text { penyakit, dan hasil } \\
\text { prediksi sistem pakar } \\
\text { menunjukkan benar } \\
\text { bahwa pasien tidak ada } \\
\text { penyakit stroke. }\end{array}$} & \multirow{7}{*}{$\begin{array}{lr}\text { FN: } & \text { banyaknya } \\
\text { kasus } & \text { masyarakat } \\
\text { yang } & \text { terdiagnosis } \\
\text { tidak } & \text { mengidap } \\
\text { penyakit } & \text { stroke, dan } \\
\text { hasil prediksi } & \text { sistem } \\
\text { pakar } & \text { salah } \\
\text { memprediksi mereka } \\
\text { mengidap } & \text { penyakit } \\
\text { stroke } & \text { atau } \\
\text { persentase } & \text { yang } \\
\text { tinggi. } & \end{array}$} & Tabel 10. Akurasi Sistem Pakar Deteksi Penyakit Stroke \\
\hline & & & Persentase Hitungan \\
\hline & & & Accuracy $\quad(3+11) /(3+3+3+11) * 100 \%=70 \%$ \\
\hline & & & $11 /(14) * 100 \%=78.57 \%$ \\
\hline & & & \\
\hline & & & $3 /(6) * 100 \%=50 \%$ \\
\hline & & & $\begin{array}{c}F 1-\text { Score } \quad((78.57 \% \times 78.57 \%) /(78.57 \%+78.57 \%)) * 2= \\
0.786\end{array}$ \\
\hline Positif & $\begin{array}{l}\text { FP: banyaknya kasus } \\
\text { masyarakat yang } \\
\text { terdiagnosis menderita } \\
\text { penyakit stroke, namun } \\
\text { sistem pakar salah } \\
\text { memprediksi bahwa } \\
\text { mereka tidak memiliki } \\
\text { atau persentase stroke } \\
\text { dibawah } 50 \% \text {. }\end{array}$ & $\begin{array}{lr}\text { TP: banyaknya kasus } \\
\text { masyarakat } r \text { yang } \\
\text { terdiagnosis } \\
\text { penyakit } & \text { stroke, } \\
\text { hasil dari } & \text { sistem } \\
\text { pakar memprediksi } \\
\text { dengan r tepat } \\
\text { masyarakat } & \text { tersebut } \\
\text { menderita penyakit } \\
\text { stroke }\end{array}$ & $\begin{array}{l}\text { Nilai terbaik dari pengujian ini adalah } 1 \text { (satu) dan yang } \\
\text { terburuk adalah } 0 \text { (nol). Seperti yang ditunjukkan pada } \\
\text { Tabel 9, skor F1 sistem pakar adalah } 0,786 \text { yang } \\
\text { menunjukkan kinerja sistem pakar yang baik. }\end{array}$ \\
\hline
\end{tabular}

Tabel 9. data pengujian Confusion Matrix

\begin{tabular}{cccc}
\hline \multirow{2}{*}{$\begin{array}{c}\text { Confusion Matrix } \\
\text { Sistem Pakar }\end{array}$} & \multicolumn{2}{c}{ Prediksi } & Total \\
\cline { 2 - 3 } Actual & $\begin{array}{c}\text { Salah oleh } \\
\text { sistem }\end{array}$ & $\begin{array}{c}\text { Benar oleh } \\
\text { Sistem }\end{array}$ & \\
\hline $\begin{array}{c}\text { Kasus } \\
\text { diagnosis } \\
\text { yang salah } \\
\text { Kasus } \\
\text { diagnosis } \\
\text { yang benar }\end{array}$ & 3 & 3 & 6 \\
& 3 & 11 & 14 \\
\end{tabular}

Kinerja sistem yang kami usulkan secara umum dinilai menggunakan data dalam matriks. Beberapa metrik, termasuk akurasi, presisi, sensitivitas (recall), $F$ measure (F1 score), dan spesifisitas diterapkan sebagai kriteria untuk melaksanakan evaluasi ini pada persamaan(6) sampai persamaan (10) tunjukkan rumus untuk metrik ini :

$$
\begin{aligned}
\text { Accuracy } & =\frac{\mathrm{TN}+\mathrm{TP}}{\mathrm{TN}+\mathrm{FP}+\mathrm{FN}+\mathrm{TP}} \times 100 \% \\
\text { Precision } & =\frac{\mathrm{TP}}{\mathrm{TP}+\mathrm{FP}} \times 100 \% \\
\text { Recall } & =\frac{\mathrm{TP}}{\mathrm{TP}+\mathrm{FN}} \times 100 \% \\
\text { Specifity } & =
\end{aligned}
$$

Data pengujian tabel 9 dengan persamaan(6) - (10) dihitung maka ditemukan akurasi sistem pakar deteksi penyakit stroke yang membandingkan sistem dengan kepakaran yaitu dokter penyakit syaraf rumah sakit bakti 


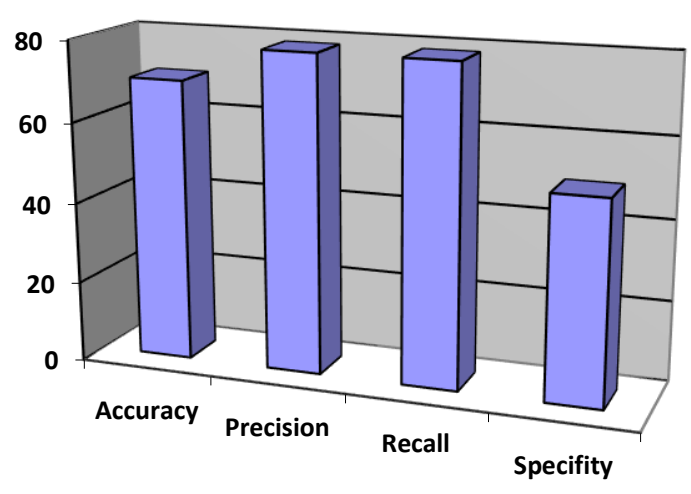

Gambar 11 Grafik Penujian Confusion Matrix

Grafik pada gambar 11 menunjukkan bahwa nilai precision dan recall menjadi nilai tertinggi pada pengujian ini dengan nilai $78.57 \%$, sedangkan Specifity menjadi nilai terendah yaitu $50 \%$.

\section{Kesimpulan}

Metode Dempster Shafer merupakan teori ketidakpastian yang dalam penerapannya melakukan perhitungan atas gejala pasien yang terindikasi stroke berdasarkan 20 gejala dan 4 penyakit. Penerapan logika fuzzy yang merupakan logika samar melakukan perhitungan atas hasil dempster shafer dengan riwayat pasien yang memiliki 9 variabel input dan 1 hasil output. Hasil pengujian sistem pakar deteksi dini penyakit stroke memperoleh hasil akurasi $70 \%$, presisi 78.57, sensitivitas $78,57 \%$ dan spesifisitas $50 \%$, dengan hasil skor F1 yaitu 0,786 yang menunjukkan keakuratan sistem pakar yang cukup baik.

\section{Daftar Rujukan}

[1] Z. Abrishami and H. Tabatabaee, "Design of A Fuzzy Expert System And A Multi-Layer Neural Network System For Diagnosis Of Hypertension," 2015.

[2] V. Adelina, D. E. Ratnawati, and M. A. Fauzi, "Klasifikasi Tingkat Risiko Penyakit Stroke Menggunakan Metode GAFuzzy Klasifikasi Tingkat Risiko Penyakit Stroke Menggunakan Metode GA- Fuzzy Tsukamoto," J. Pengemb. Teknol. Inf. dan Ilmu Komput. Univ. Brawijaya, 2018.

[3] J. R. Villar, S. González, J. Sedano, C. Chira, and J. M. TrejoGabriel-Galan, "Improving human activity recognition and its application in early stroke diagnosis," Int. J. Neural Syst., 2015.

[4] T. Djatna, M. K. D. Hardhienata, and A. F. N. Masruriyah, "An intuitionistic fuzzy diagnosis analytics for stroke disease," $J$. Big Data, 2018.

[5] M. B. Ulum and V. Tundjungsari, "Designing fuzzy expert system to identify child intelligence," Telkomnika (Telecommunication Comput. Electron. Control., 2018.

[6] A. Sulistyohati, T. Hidayat, K. Kunci: Ginjal, S. Pakar, and M. Dempster-Shafer, "Aplikasi Sistem Pakar Diagnosa Penyakit Ginjal Dengan Metode Dempster-Shafer," Semin. Nas. Apl. Teknol. Inf., 2008.

[7] B. H. Hayadi and A. Setiawan, "Sistem Berbasis Pengetahuan Dengan Menggunakan Fuzzy Tsukamoto (Untuk Kesehatan Dan Perawatan Bayi)," Semin. Nas. Teknol. Inf. dan Komun. 2016, 2016.

J. Kanggeraldo, R. P. Sari, and M. I. Zu, "Sistem Pakar Untuk Mendiagnosis Penyakit Stroke Hemoragik dan Iskemik Menggunakan Metode Dempster Shafer," J. RESTI (Rekayasa Sist. dan Teknol. Informasi), 2018.

[9] Y. Yueniwati, Deteksi Dini Stroke Iskemia:dengan Pemeriksaan Ultrasonografi vaskular dan variasi genetika. 2015.

[10] S. H. Kusumadewi, "Fuzzy Multi-Attribute Decision Making (Fuzzy MADM)," Graha Ilmu Yogyakarta, 2006.

[11] L. Laurentinus and S. Rinaldi, "Implementasi Metode Analytical Hierarchy Process dan Simple Additive Weighting untuk Pemilihan Dosen Terbaik Studi Kasus STMIK Atma Luhur," J. Teknol. Inf. dan Ilmu Komput., 2019. 